\title{
再生骨材の品質が再生コンクリートの品質に及ぼす影響 INFLUENCE OF QUALITY OF RECYCLED AGGREGATE
ON QUALITY OF RECYCLED AGGREGATE CONCRETE
}

\author{
菊池 雅史*，道正泰弘**，安永 亮***，江原 恭二**** \\ 增田彰***** \\ Masafumi KIKUCHI, Yasuhiro DOUSYOU, Akira YASUNAGA, \\ Kyouji EHARA and Akira MASUDA
}

\begin{abstract}
The availability and applicability of recycled aggregate as aggregate resources have already proved by many researchers. The other hand, practical application of recycled aggregate .. concrete containing this type of aggregate for structual concrete has never adopted in Japan. To promote practical application of recycled aggregate concrete, there are many points that must be solved concerning the correlation between qualities of recycled aggregate and properties of recycled aggregate concrete. From this point of view, 35 types of recycled aggregate concrete produced from seven types of recycled aggregates, and properties of this type of concrete, such as fresh concrete. unit weight of dry condition. strength, drying shrinkage, neutralization, freezing and thaning, and so on, were examined:

The correlation between qualities of recycled aggregate and properties of recycled aggregate concrete were clarified through these test results.
\end{abstract}

Ieywords : recycled aggregate, recycled lightweight aggregate, recycled aggregate concrete, recycled aggregate lightweight concrete, correlation between aggregate and concrete, value of relative quality,

再生骨材, 再生軽量骨材, 再生コックリート, 再生軽量コックリート, 骨材とコックリートの相関性, 相対品質値

\section{1.はじめに}

解体工事に伴って発生するコンクリート塊の再資源化 に関する研究は比較的早くから進められてきている。し かし、本格的な奏用化の研究が着手されたのは、「法律 第 48 号: 再生資源の利用の促進に関する法律」が制定 された1991 年以降といえる。1994 年の「コンク リート副産物の再利用に関する用途別品質基準案（建設 省技調発第８８号）」は、コンクリート用再生骨材の実 用化に際しての、品犋の暫定的な目安を示すことによっ て利用促進を図ることとなった。

このように、実用化のための法令等は次第に整ってき ているが、技術的には解決すべき研究課題が残されてい る。その第 1 は再生骨材の品質の適切な評価方法であり、 第 2 は再生骨材の品質が再生コンクリートの品質に及ぼ す影櫭を解明することであり、第 3 は再生骨材の品質に 応じた所要品質コンクリートの適切な調合設計を確立す ることである。
本研究は、このような観点から、これまで筆者らが行 ってきた研究成果(1)，2，3)，4)をもとに、再生骨材の品 質と再生コンクリートの品質との相関珄について総合的 に検討したものであり、これらを踏まえて再生コンクリ 一トの適切な調合設計を確立するための基礎的資料を得 ようとするものである。

\section{2. 既往研究の沿革}

わが国における再生骨材および再生コンクリートに関 する研究はおおよそ以下の 3 つに大別できる。

(1) 1973 年の第 1 次石油危機を契機として着手された もので、良質な骨材資源の枯渴に伴う代替骨材としての 適用性に関する研究の位置付けであり、研究の背景には 最終処分場の確保が困難となりつつあった当時の状況も ある。内容的には、再生骨材の使用によるコンクリート の品質低下に関する研究 ${ }^{5)}$ ，7) が多い。

(2) 1980 年代から着手され、再生骨材の積極的な利用
* 明治大学理工学部建築学科 助教授・工博

** 東京電力(窲電力技術研究所棈造研究室 主任·工修

*** 明治大学 大学院生 (現住友金属鉱山侏)）。 工修

**** 明治大学 大学院生 (現清水建設侏)広島支店) - 工修

***** 東京電力侏電力技術研究所構造研究窒 主任研究員
Assoc. Prof., Dept of Architecture, Science \& Tech, Meiji Univ. Dr. Eng.

Researcher., Civil Eng. and Architecture Dept,.Power R \& D Center, TEPCO., M. Eng.

Graduate Student, Meiji Univ. (at present, Sumitomo Metal Mining Corp.), M. Eng.

Graduate Student, Meiji Univ. (at present, Shimizu Hiroshima Branch.), M. Eng.

Senior Researcher., Civil Eng. and Architecture Dept, Power R \& D Center, TEPCO. 
のための, あるいは高度利用に関する研究で、普通骨材 の一部を部分的に置換することにより、構造用骨材とし ての適用性の確認および実用化のための基礎的研究日)，8) が中心となっている。

(3) 1990 年代には、再生骨材としての利用の観点のみ ならず、永久的な骨材資源として、また地球環境を考慮 した再生骨材のあり方等に関する研究 12，2)，3，4)，日2． 10) が着手されてきている。

\section{3. 本検璟に用いた再生骨材}

本検討に用いた再生骨材の製造方法およびその物性に ついて、以下に示す。

3ー1 原コンクリート

表ー 1 に示すように、普通骨材および構造用人工軽量 骨材を用い、実験室および骨材製造工場で作製した王縮 強度の異なる普通コンクリート 3 種類(R1，R2，R3)および 軽量コンクリート 1 種を 3 種類(RL1, RL2, RL3)、2 7 〜 28 年前に製造された無仕上げの軽量コンクリート2 種 の P C a パネル 1 種類(RL4) の合計 7 種類を原コンクリ ートとした。

\section{3-2 再生骨材の製造}

実験室および骨材製造工場で作製した原コンクリート については、ほぼ作製後 2 力月〜 1 年後の間で、また、 P C a パネルについては、製造後 $27 \sim 28$ 年後に再生 骨材の製造に供した。製造は図ー 1 に示すジョークラッ シャ一を用いて、そのオープンセットを普通コンクリー トにあっては $20 \mathrm{~mm}$, 軽量コンクリートにあっては $15 \mathrm{~mm}$

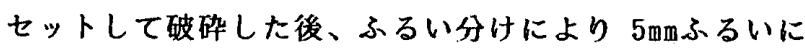
留まるものを粗骨材、通過するものを細骨材とした。

\section{3-3 再生骨材の物性}

普通コンクリートを原コンクリートとして製造した骨 材（以下、再生骨材という）および軽量コンクリートを 原コンクリートとして製造した骨材（以下、再生軽量骨 材という) の外観, 主要物性をそれぞれ写真一 1 および
表一 2 に示す。

(1) 外 観

再生骨材および再生軽量骨材のいずれもその形状は砕

表ー1 本検討で用いた各種骨材の概要

\begin{tabular}{|c|c|c|c|c|c|c|c|}
\hline \multicolumn{4}{|c|}{ 試 験 体 掫 要 } & \multirow{2}{*}{ 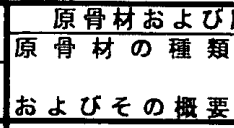 } & \multirow{2}{*}{$\begin{array}{r}\text { 原コン } \\
\text { 調 } \\
\text { 合 } \\
\text { @ } \\
\end{array}$} & \multirow{2}{*}{ 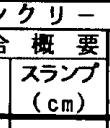 } & \multirow{2}{*}{ 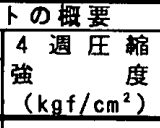 } \\
\hline 乎 & & 名 & 記 号 & & & & \\
\hline \multicolumn{2}{|c|}{ 普 } & 䋆骨材 & N & 川砂 & - & - & \\
\hline \multicolumn{2}{|c|}{ 通 } & 租骨材 & G & $\begin{array}{r}\text { 硬留砂岩砾石 } \\
\text { (JIS A 5005) }\end{array}$ & - & $\longrightarrow$ & \\
\hline \multirow{2}{*}{\multicolumn{2}{|c|}{ 蛼 }} & \multirow{2}{*}{ 粗骨材 } & $\mathrm{F}$ & 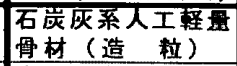 & - & - & \\
\hline & & & L & 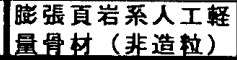 & - & - & \\
\hline \multirow[t]{3}{*}{ 百 } & 㝵 & \begin{tabular}{|l|} 
細骨㷊 \\
耤骨材 \\
\end{tabular} & $\begin{array}{|lll|}R & 1 & s \\
R & 1 & g \\
\end{array}$ & \multirow{3}{*}{ 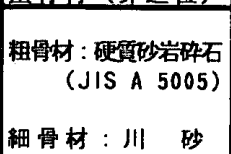 } & & \multirow{3}{*}{2} & $\begin{array}{llll}1 & 1 & 7 & 3 \\
8 & 1 & 6 \\
6\end{array}$ \\
\hline & & 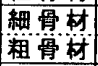 & $\begin{array}{lll}R & 2 & 5 \\
R & 2 & g \\
\end{array}$ & & $\begin{array}{|ll|}3 & 5 \\
4 & 5 \\
\end{array}$ & & $\begin{array}{lll}7 & 1 & 4 \\
5 & 1 & 8 \\
\end{array}$ \\
\hline & & \begin{tabular}{|l|} 
細骨杨 \\
榸骨材 \\
\end{tabular} & 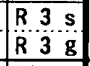 & & \begin{tabular}{|l|l|}
5 & 5 \\
6 & 5 \\
\end{tabular} & & 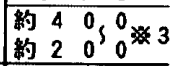 \\
\hline \multirow[t]{2}{*}{ 再 } & \multirow[t]{2}{*}{1} & 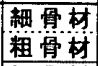 & \begin{tabular}{|l|}
$R L 1 s$ \\
$R L I I g$ \\
\end{tabular} & \multirow{3}{*}{ 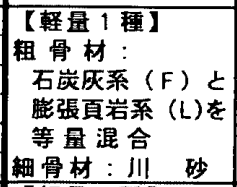 } & $\begin{array}{ll}4 & 5 \\
\end{array}$ & \multirow{3}{*}{$\begin{array}{r}\$ 4 \\
22 \pm 2\end{array}$} & 472 \\
\hline & & $\begin{array}{l}\text { 細骨材 } \\
\text { 相 } \\
\end{array}$ & $\begin{array}{l}R L 2 s \\
R L 2 \mathrm{~g} \\
\end{array}$ & & & & $\begin{array}{lll}3 & 9 & 7\end{array}$ \\
\hline & 種 & 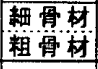 & \begin{tabular}{|l|}
$R L 3 s$ \\
$R L 3 g$ \\
$R$
\end{tabular} & & $\begin{array}{ll}7 & 0\end{array} \mid$ & & $\begin{array}{lll}2 & 6 & 3\end{array}$ \\
\hline & \multirow[t]{2}{*}{2} & 梱骨材 & $\mathrm{RL} 4 \mathrm{~s}$ & \multirow{2}{*}{$\begin{array}{l}\text { 【喤量 } 2 \text { 種】 } \\
\text { 赥・粗骨材ともに } \\
\text { 腿張頁岩系 }\end{array}$} & \multirow[b]{2}{*}{ 不 } & \multirow[b]{2}{*}{ 明 5} & \multirow[b]{2}{*}{ 教 400} \\
\hline int & & 粗骨材 & $R L 4 B$ & & & & \\
\hline
\end{tabular}

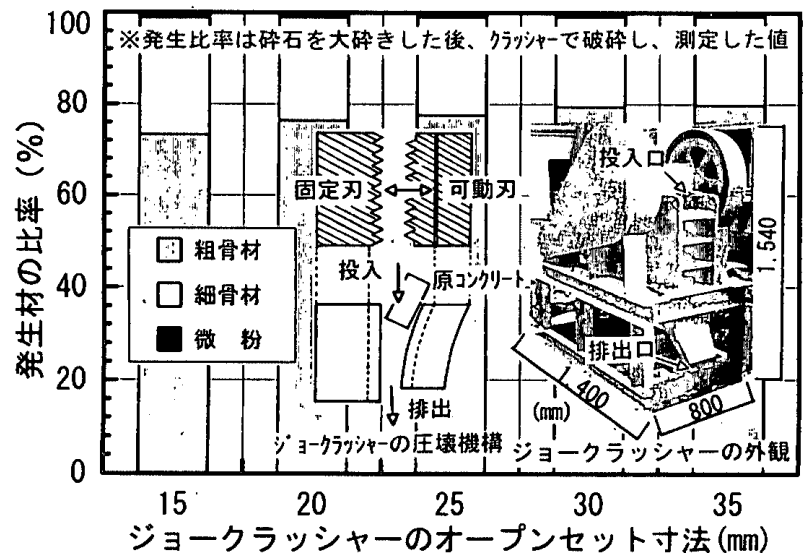

図ー1 再生骨材の製造に供したジョークラッシャ一の概要

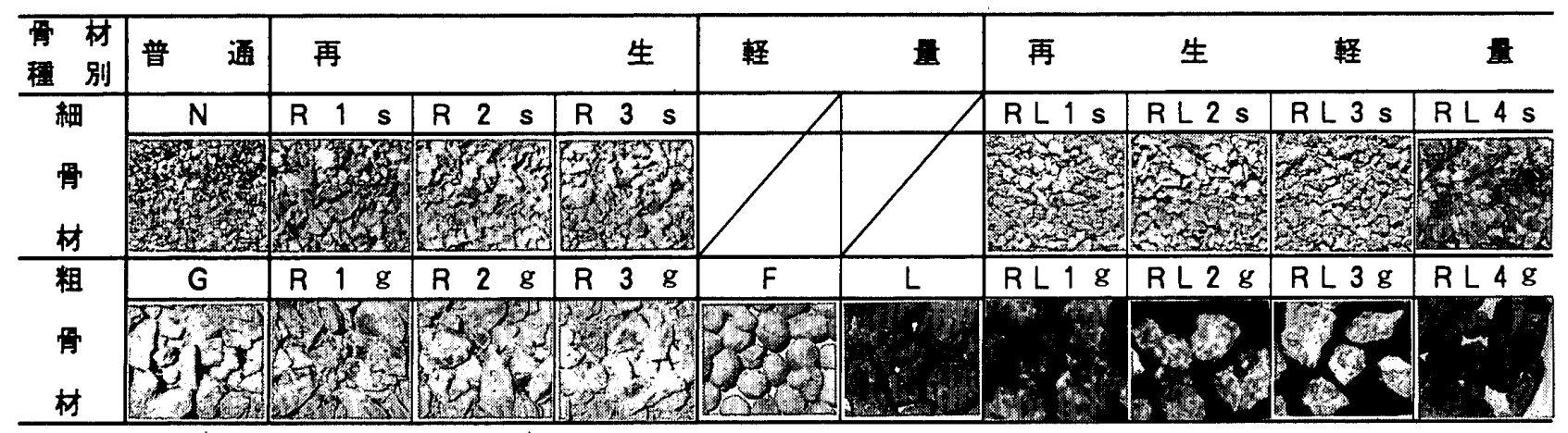

写真一1 各種骨材の外観 
表ー2 本検討で製造，使用した各種骨材の主要物性

\begin{tabular}{|c|c|c|c|c|c|c|c|c|c|c|c|c|c|c|c|c|c|c|c|}
\hline \multirow{2}{*}{ 試 } & \multirow{2}{*}{ 概 } & \multirow{2}{*}{ 要 } & \multicolumn{3}{|c|}{ 梱 } & \multicolumn{2}{|c|}{ 骨 } & \multicolumn{3}{|c|}{ 材 } & \multicolumn{3}{|c|}{ 粗 } & \multicolumn{3}{|c|}{ 骨 } & \multicolumn{3}{|l|}{ 材 } \\
\hline & & & \multirow{2}{*}{ 普 通 } & \multirow{2}{*}{ 再 } & & \multirow{2}{*}{ 生 } & \multirow[b]{2}{*}{1} & \multirow[t]{2}{*}{ 生 } & \multirow{2}{*}{$\begin{array}{l}\text { 整 } \\
\text { 種 }\end{array}$} & \multirow{2}{*}{$\begin{array}{l}\text { 量 } \\
2 \text { 種 }\end{array}$} & \multirow{2}{*}{ 普 通 } & \multirow{2}{*}{ 軽 } & \multirow[b]{2}{*}{ 量 } & \multirow{2}{*}{ 再 } & & \multirow[b]{2}{*}{ 生 } & \multirow{2}{*}{\begin{tabular}{|c|} 
再 \\
1 \\
\end{tabular}} & \multirow{2}{*}{\multicolumn{2}{|c|}{\begin{tabular}{l|l} 
租 & 2 程 \\
\end{tabular}}} \\
\hline & 試 & 験 & & & & & & & & & & & & & & & & & \\
\hline 騃 & 方 & 法 & $\mathrm{N}$ & $\mathrm{R} 1 \mathrm{~s}$ & R2s & R 3 & RL1s & $\mathrm{RL} 2 \mathrm{~s}$ & $R L 3 s$ & RL4s & $G$ & $F$ & $L$ & R18 & $R 2$ & R3g & \begin{tabular}{|l|l|l|}
$R L 1 g L 2 g$ \\
\end{tabular} & RL3g & RL4g \\
\hline 大寸法 $(\mathrm{m} \mathrm{m})$ & & & 5 & & 5 & & & & 5 & & 20 & 15 & 5 & & 20 & & 15 & 5 & \\
\hline 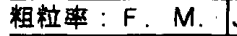 & JIS A & 1102 & 2. 92 & 3.61 & 3.86 & 3.72 & 3.41 & 3.51 & 3.46 & 3.89 & 6.72 & 6.53 & 6.62 & 6.71 & 6.69 & 6.66 & $6.31 \mid 6.49$ & $6.45 \mid$ & 6.30 \\
\hline 絶 & 細桶材.JIS & $S A 1109$ & 2.58 & 2.03 & 2.08 & 2.01 & 1.71 & 1.57 & 1.66 & 1.34 & 2.60 & 1.35 & 1.29 & 2.35 & 2.32 & 2.32 & \begin{tabular}{|l|l|}
1.77 & 1.76 \\
\end{tabular} & 1.76 & 1.41 \\
\hline 里表 乾 時 & 粗禪材.JIS & $S$ A1110 & 2.61 & 2.32 & 2.32 & 2.29 & 2.01 & 1.93 & 1.98 & 1.79 & 2.63 & 1.55 & 1.42 & 2.44 & 2.42 & 2.44 & \begin{tabular}{|l|l|}
1.98 & 1.98 \\
\end{tabular} & 1.98 & 1.67 \\
\hline 水率 (x) & F, L:JIS & $S$ A1135 & 1.18 & 14.3 & 11.5 & 13.9 & 17.9 & 23.0 & 19.6 & 33.5 & 0.89 & 14.5 & 9.86 & 3.96 & 4.39 & 5.05 & \begin{tabular}{|l|l|}
12.1 & 12.3 \\
\end{tabular} & 12.5 & 19.0 \\
\hline 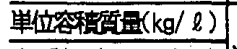 & & & 1.74 & 1.27 & 1.32 & 1.16 & 1.17 & 1.15 & 1.18 & 0.83 & 1.54 & 0.82 & 0.81 & 1.31 & 1.30 & 1.30 & 0.980 .96 & 0.95 & 0.74 \\
\hline 英栍率 (\%) & & & 67.6 & 62.6 & 63.5 & 57.7 & 68.2 & 73.2 & 71.1 & 67.5 & 59 & 60.7 & 62.1 & 55.6 & 56.3 & 56.1 & \begin{tabular}{|l|l|}
55.7 & 54.7 \\
\end{tabular} & 54.2 & 52.6 \\
\hline 材 40 破碎値(X) & & & - & - & - & - & - & - & - & - & 13.8 & 39.3 & 39.1 & 18.4 & 22.8 & 25.2 & 30.532 .4 & 38.1 & 36.1 \\
\hline $10 \%$ 破碚力 $(\mathrm{t})$ & 8 & & - & - & - & - & - & - & - & $=$ & - & 9.54 & 8.56 & - & - & - & \begin{tabular}{|l|l|}
8.97 & 7.73 \\
\end{tabular} & 7.13 & 6.43 \\
\hline
\end{tabular}

石状であるが、全体的には原コンクリートの圧樎強度が 小さいものほど、稜線の角張りは鈍くなり、形状もやや 偏平になる傾向が観察された。また、再生骨材において は、原コンクリートの強度が大きいものほど、もとの骨 材（以下、原骨材という）の破断が顕著であった。

(2) 粒 度

粗骨材のふるい分け試験結果を図ー 2 に示す。再生粗 骨材の粒度分布は、いずれも15㥸でJASS 5に規定する普 通骨材の標準粒度の通過率を越える檤を示した。

一方、再生軽量粗骨材は、JIS A 5002に規定する標準 粒度範囲に適合した。細骨材については、再生細骨材お よび再生軽量細骨材のいずれにおいても、0.3〜 2.5mm の間でそれぞれに規定する標準粒度範囲に適合しない通 過率を示し、表一 2 に示すように、粗粒率3.41を越える 粗目の骨材となった。また、原コンクリートの王縮強度 が骨材の粒度に及ぼす影響は認められなかった。

(3) 比重

粗骨材の絶乾比重は、再生粗骨材で 2.3 程度, 軽量コ ンクリート 1 種および 2 種を原コンクリートとする再生 軽量細骨材ではそれぞれ 1.8 弱および 1.4 程度であり、 いずれも普通コンクリートおよび軽量コンクリートの一 般的な気乾比重の值とほぼ同等であった。

細骨材の絶乾比重は、再生細骨材で 2.0〜 2.1の範囲 であり、普通モルタルの気乾比重とほぼ同等の值となっ た。一方、原コンクリートを軽量コンクリート1種およ び 2 種とした再生軽量細骨材では、それぞれ1.57〜1.71 および1.34であり、いずれも軽量コンクリート 1 種およ び 2 種の一般的な気乾比重の値に比へてやや小さい。

また、原コンクリートの王䈹強度が骨材の比重に及ぼ す影響については、今回の実験の範囲では、明確な㑯向 はみられなかった。

(4) 吸水率

粗骨材の吸水率は、再生粗骨材でほぼ 4 〜 \%の範井 にあり、原コンクリートの強度が大きくなるのに伴って 吸水率は小さくなる傾向が想められた。再生軽量粗骨材

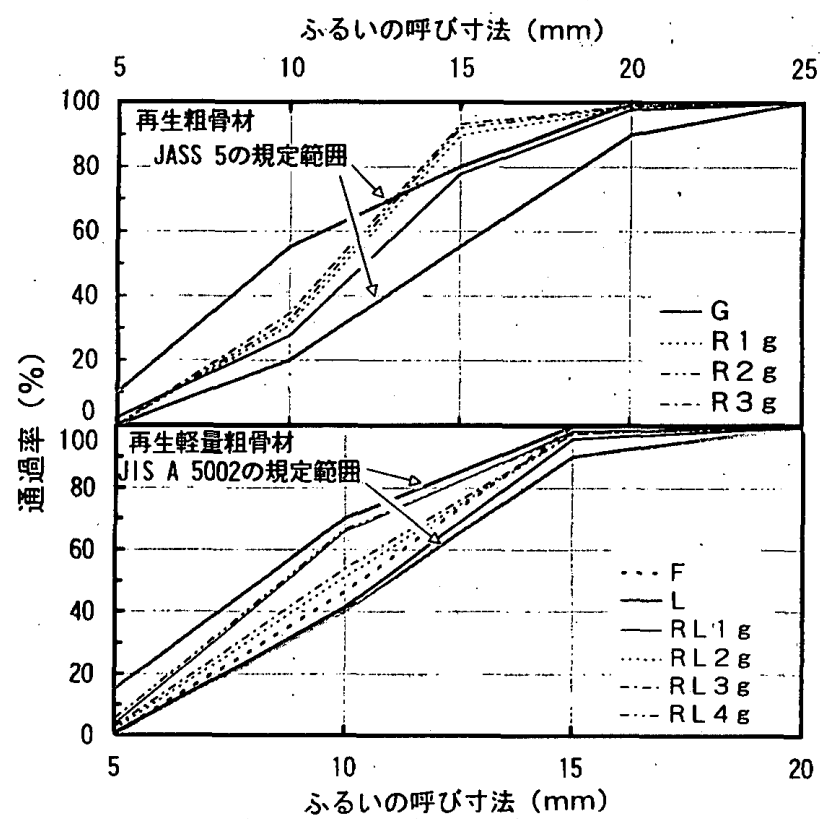

图ー2 本検討で用いた各種粗骨材のふるい分け試験結果

の吸水率は、原コンクリートを軽量コンクリート 1 種お よび 2 種とした場合で、それぞれ約 $12 \% ， 19 \%$ あった。

細骨材は粗骨材に比べて再生細骨材では $2.5 \sim 3.5$ 倍, 再生軽量細骨材では1.5〜2 倍の高い吸水率であった。

\section{（5）実積率}

粗骨材の実積率は、再生粗骨材では $56 \%$ 前後; 再生軽 量粗骨材では53〜 56\%程度であり、いずれも原骨材の実 皘率より小さな值であった。

細骨材については、再生細骨材で58〜 64\%，再生軽量 細骨材で68〜 73\%の範囲で、前者は原骨材に比べてかな り小さな値であり、後者は同等か大きめの値であった。

(6) 骨材強度

骨材強度試験結果を表一 2 に示す。硬質砂岩砕石 (40 $\mathrm{t}$ 破砕値: $13.8 \%$ ）を用いた压䈹強度 $200 \sim 1200 \mathrm{kgf} / \mathrm{cm}^{2}$ の原コンクリートから製造した再生粗骨材の骨材強度は、 $40 \mathrm{t}$ 破碎值で、ほぼ18〜25\%の範囲であった。一方、石 炭灰系人工軽量骨材（10\%破研力:9.54t）, 膨張頁岩系人 
工軽量骨材（10\%破砕力:8.56t）を用いた医樎強度 260 〜 472kgf/ cmi゙の原コンクリートから製造した再生軽量粗 骨材については、10\%破砕力でほぼ6.4 9.0七の範囲で あり、原骨材に比へて、同等もしくは小さくなる傾向が みられた。また、原コンクリートの圧樎強度との関係に ついては、再生粗骨材および再生軽量粗骨材のいずれに おいても、压樎強度が大きくなるのに伴って骨材強度も 大きくなる㑯向が認められた。

本検討で骨材强度の判定に用いたB.S. 812法は、一定 の容器中に所定の見卦けの容皘試料を詰めて王密する試 験であることから、試料骨材の実積率が試験結果に及ぼ

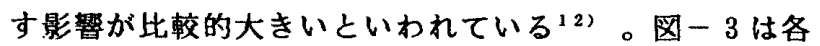
種骨材の压密変位を、図ー4 は実皘率と $40 \mathrm{t}$ 破研値また は10\%破碎力の関係を示したものである。一般に、実積 率の小さな骨材は角張りを有しており、同一の荷重に対 して王密変位が大きくなり、その初期の変位の段階で角 張っている部分が小片に破砕されることになる。従って、 試料の強度が同一の場合には、実積率が小さいものほど 骨材強度も小さく判定される場合が多い。また、図一 5 は原コンクリートの圧䨂強度と骨材強度の関係を示した ものであるが、両者の間には相関性が認められる。

\section{4. 再生コンクリート}

前項で示した再生骨材を用いたコンクリート（以下、 再生コンクリートという) および再生軽量骨材を用いた コンクリート（以下、再生軽量コンクリートをいう）に ついて、その実験概要，実験結果およびその検討を以下 に示す。

\section{4-1 実験概要}

(1) 使用材料

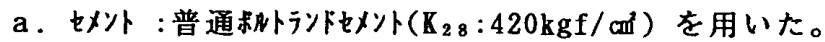
b. 骨 材：再生骨材 3 種類, 再生軽量骨材 4 種類, 比 較用として普通骨材およひ人工軽量骨材を用いた。これ ら骨材の種類, 記号および主要物性は表ー 2 に示した通 りである。

c. 混和剂：水セメント比 $35 \%$ 以下のものには、アれれ 系高性能 A E 減水剂およびレジ 系空気連行補助剂を、水 セメント比 $45 \%$ 以上のものには、リタニンス月7ォン酸系 A E 減水剤および樹脂酸塩系空気連行補助剤を用いた。

(2) 試料コンクリート

本検討に用いた試料コンクリートの種類, 調合概要等 を表一 3 に示す。

a. 種 類 : 骨材種類, 骨材の組合せ, 再生骨材の普通 骨材への混合割合（以下、固換率という）おょび水セメ ント比等を変化させて合計 44 種類の試料コンクリート を作製した。

b．調 合：水セメント比は、 $25,35,45,55$ および $65 \%$

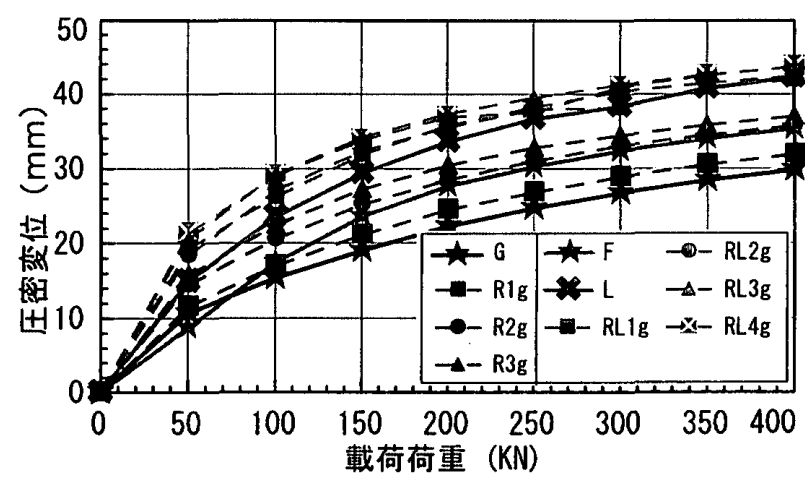

图一３各種骨材の圧密変位試験結果

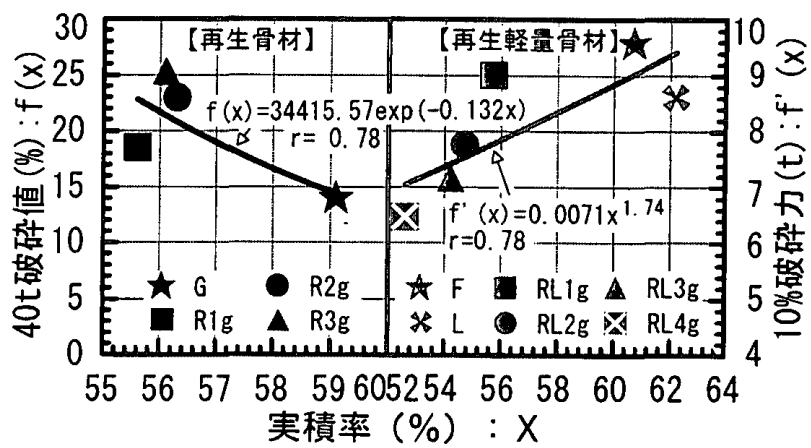

图-4 各種骨材の実積率と骨材強度の関係

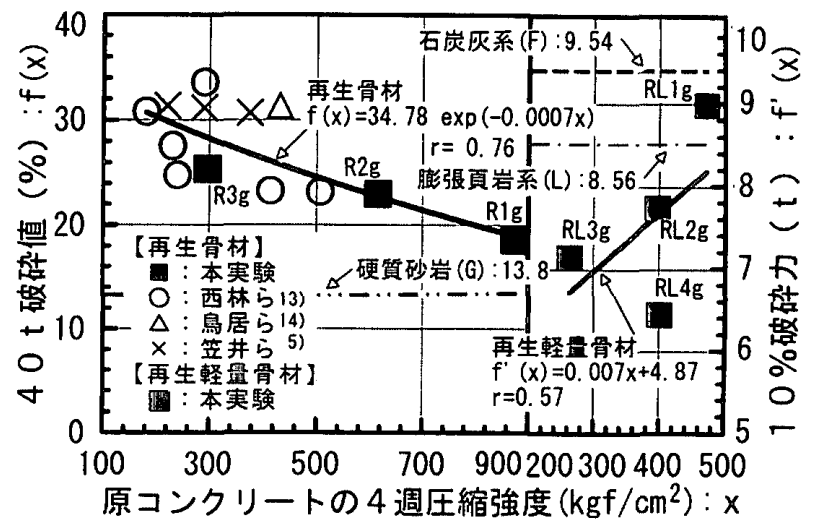

※1. 各試験とも圧罱型のショークラッシャーで破碚した ※2. 骨材の最大寸法は本実験以外は $25 \mathrm{~mm}$

図－5 原コンクリートの 4 週王縮強度と再生骨材, 再生軽量骨材の骨材強度の関係

の 5 水準, 細骨材率は、水セメント比, 骨材の実皘率お よび置換率等を考虑して原骨材使用の場合に対して 1.1 〜3.3\%の間で增減した。単位水量および混和剂の量は 所要のスランプおよび空気量が得られるように調整した。 c 、目標スランプおよび空気量：再生コンクリートでは、 スランプ $18 \pm 2 \mathrm{~cm}$, 空気量 $3 \pm 1 \%$ (ただし、凍結蜃 解試釦用は $4.5 \pm 1.5 \%$ とし、軽量コンクリートでは、 スランプ $21 \pm 2 \mathrm{~cm}$, 空気量 $4.5 \pm 1.5 \%$ とした。

（3）試験項目, 試倹体および試験方法

フレッシュコンクリートでは、スランプ, 空気量およ び単位容積質量を, 硬化したコンクリートでは気乾単位 
容積質量, 王樎 ・引張・曲げ強度, 乾燥収箱, 中性化, 塩分遮蔽性および凍結融解の諸試験を行った。試験体お よび試験方法等の概略を表一 4 に示す。

\section{4-2 害験軺果およひその検討}

4-2-1 フレッシュコンクリートの性質

水セメント比の異なる 5 種類の再生コンクリートおよ び 4種類の再生軽量コンクリートのスランプと空気量に ついて、それぞれ平均值およびその範囲で示したものが 図一 6 である。

(1) スランプ

a 、再生コンクリート：表一 3 に示すように、1 $8 \pm 2$ cmのスランプを得るための単位水量は、再生骨材による 置換率を細・粗骨材とも $1.5 \%$ とした再生コンクリート においては、普通コンクリートに比べて、 $4 \sim 8 \mathrm{~kg} / \mathrm{m}^{3}$ 増加した。

一方、細・粗骨材とも $30 \%$ または粗骨材のみ 100 $\%$ 置換した場合、いずれも $8 \sim 12 \mathrm{~kg} / \mathrm{m}^{3}$ の增加となった。

また、目標スランプに対する変動は再生細骨材の置換 率の增加に伴い、大きくなる傾向が誋められた。

表ー3 試料コンクリートの種類および調合概要

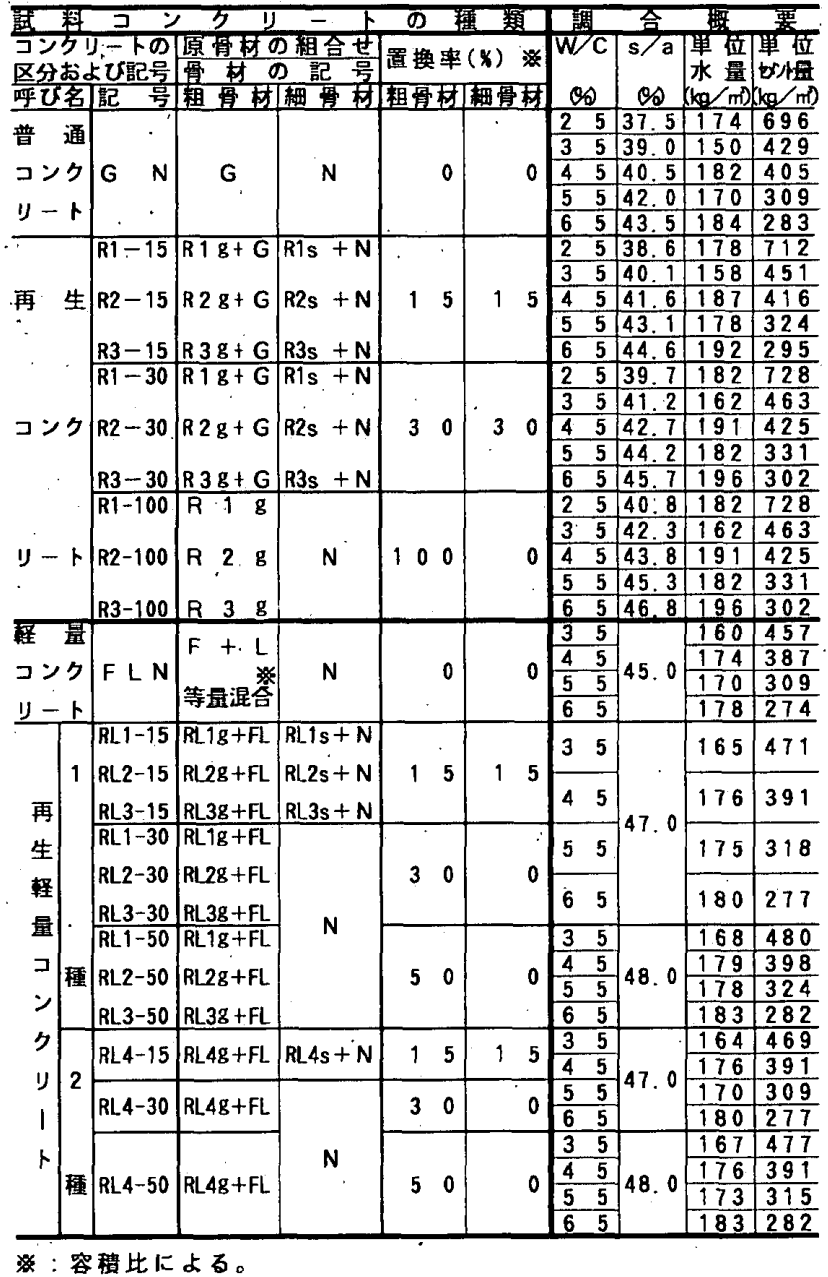

b. 再生軽量コンクリート : $21 \pm 2 \mathrm{~cm}$ のスランプを得 るための単位水量は、再生軽量骨材による置換率を細・ 粗骨材とも $15 \%$ および粗骨材のみ $3.0 \%$ 置換した再生 軽量コンクリートでは、軽量コンクリート 1 種に比べて $2 \sim 5 \mathrm{~kg} ＼textrm{m}^{3}$ の増加となった。

一方、再生軽量粗骨材のみ $50 \%$ 置换した場合では、 $2 \sim 8 \mathrm{~kg} / \mathrm{m}^{3}$ の增加となった。

以上のことは、再生骨材および再生軽量骨材の特性, 即ち、実積率の小ささと骨材の破断面のポアの多さによ るもので、両者に起因する空隙を充填するためのモル夕 ル分の増加と、骨材形状の悪さに起因するコンシステン シ一の低下の 2 つが主な原因と考えられる。

\section{(2) 空気量}

表-4 本検討で行った試験項目，試験体および試験方法等 の概略

\begin{tabular}{|c|c|c|c|c|c|}
\hline 試 & 験 項 目 & $\begin{array}{c}\text { 厨驗体形状 } \\
(\mathrm{cm})\end{array}$ & 試 倹 & 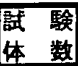 & 㦈 生 条 件 案 \\
\hline & I & & JIS A 1101 & & 温度 : $20^{\circ} \mathrm{C}$ \\
\hline \multirow[b]{2}{*}{$7 \cdot 9 \|$} & 空 気 量 & & \begin{tabular}{|llll}
$J I S$ & $A$ & 1128 \\
\end{tabular} & - & \\
\hline & -卜应位容皘質量 & & Jis A 1116 & & 湿度：RH80\% \\
\hline & 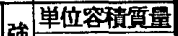 & & \begin{tabular}{|l|l|}
$J I S$ A 1108 \\
\end{tabular} & & 所定材粉祀 $20^{\circ} \mathrm{C}$ 水中 \\
\hline \multirow[t]{2}{*}{ 硬化位 } & 理些蹜强度 & $10 \phi \times 20$ & JIS A 1108 & 各3体 & - 気草單位容皘質量試 \\
\hline & 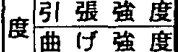 & $10 \times 10 \times 40$ & \begin{tabular}{|l|} 
JIS A 1113 \\
JIS A 1106 \\
\end{tabular} & & 後 $20^{\circ} \mathrm{C}, \mathrm{RH} 60 \mathrm{x}$ 気中13週 \\
\hline \multirow{3}{*}{ コンク } & 和 中性化 1 & & 7x/-6725(法 & & 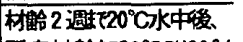 \\
\hline & 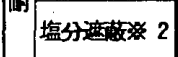 & $10 \times 10 \times 20$ & 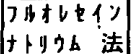 & & 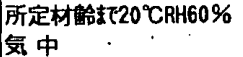 \\
\hline & 久乾蜗収縮 & & $\begin{array}{l}\text { JIS A } 1129 \\
\text { JנN }-4-\text { - 法 }\end{array}$ & 各 2 体 & 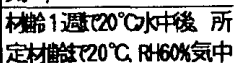 \\
\hline リート & 姓東桔 融 解 & $10 \times 10 \times 40$ & $\begin{array}{l}\text { ASTM C 666A } \\
\text { JIS A } 1127\end{array}$ & & 28 日20 $0^{\circ} \mathrm{C}$ 水中 \\
\hline
\end{tabular}

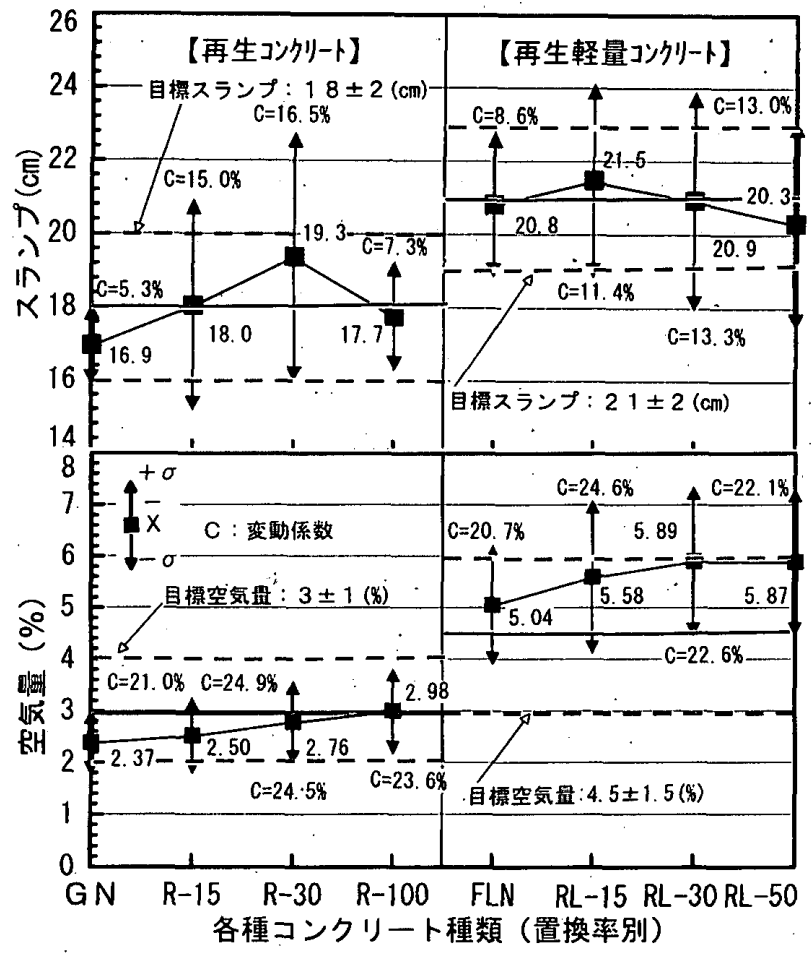

图ー6 各種コンクリートのスランプおよび空気量試験結果 
再生骨材および再生軽量骨材の骨材修正係数は、それ ぞれ $0.2 \sim 0.4 \%, 1.5 \sim 2.4 \%$ 範囲にある。図一6に 示す空気量は、これらの骨材修正係数を差し引いた値で ある。

目標空気量に対する変動は、再生細骨材および再生軽 量細骨材を置換した場合で大きくなる傾向がみられた。

\section{4-2－2 硬化したコンクリートの性質}

\section{（1）単位容積質量}

再生コンクリートの気乾単位容積質量は、2.1 2.4 $\mathrm{kg} / \ell$ で、普通コンクリートの $2.3 \sim 2.4 \mathrm{~kg} / \ell$ に比へる と、同等もしくは若干小さくなった。再生軽量コンクリ

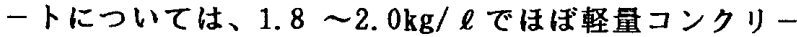
ト 1 種の範囲にある。

各種コンクリートの綀上がり時単位容積質量 $(\rho \mathbb{I})$ と 気乾単位容皘質量（ $\rho \mathrm{d} ）$ の関俰を図一 7 に示す。これに よると、骨材種類および置換率に係わらず直線的な相関 関係がみられる。

また、再生コンクリートでは練上がり時に比べて0.01 $\sim 0.07 \mathrm{~kg} / \ell$, 再生軽量コンクリートでは $0.05 \sim 0.15 \mathrm{~kg}$

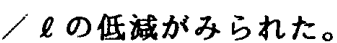

\section{（2） 4 週圧籍強度}

図一 8 は、各種コンクリートの 4 週圧䈹強度を骨材種 類および置換率別にプールし、その平均した值をそれぞ れ普通コンクリートおよび軽量コンクリートを基準とし たときの強度比で示したものである。

a．再生コンクリート：再生骨材の種類の影響は、水セ メント比 $25 \sim 65 \%$ の各平均値では、普通コンクリー トに対して、R 1 および R 2 においては $90 \%$ 以上の強 度が得られ、水セメント比 $45 \sim 55 \%$ 範囲では、ほ ぼ同等の強度が得られている。

再生骨材の置換率の影響については、細・粗骨材とも に $30 \%$ 置換した R-30において、若干低下する㑯向 がみられたものの相対的にはそれほよ゙顕著ではない。

また、水セメント比 $45 \%$ \%限定すれば、粗骨材を全 量置换したRー100において高い強度が得られている。 b. 再生軽量コンクリート: 再生軽量骨材の種類の影皚 については、水セメント比 $55 \%$ よむひ $65 \%$ の一部を 除き、軽量コンクリートに比へて高い強度を示した。

再生骨材の置換率の影響については、粗骨材のみ 30 \%および $50 \%$ 置換した場合に高い強度が得られている。

図-9 は、各種コンクリートのセメント水比と 4 週圧 樎強度の関係を示したものであり、再生コンクリートお よび再生軽量コンクリートともに直線的な相関関係がみ られた。このことから、調合設計に際しては、この種の コンクリートでも、従来の水セメント比算定式の適用が 可能といえる。

（3）引張, 曲げ強度

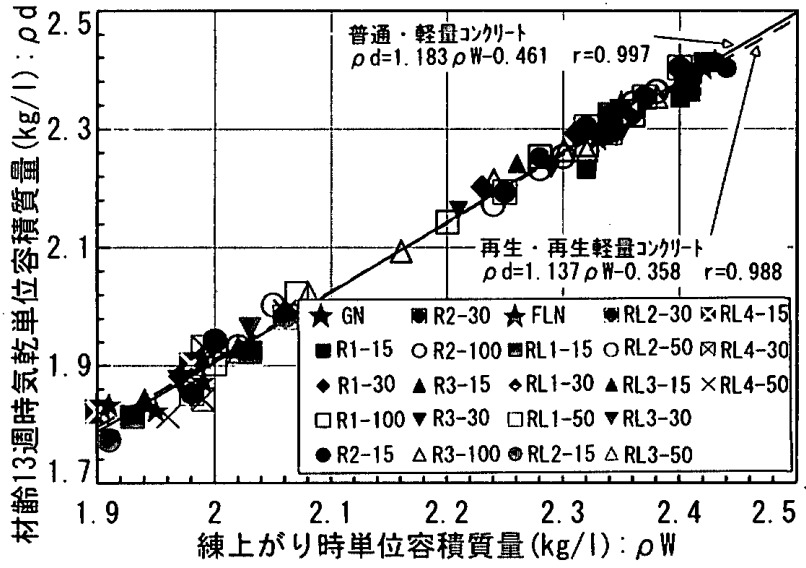

図-7 各種コンクリートの練上がり時単位容皘質量と 気乾単位容積質量の関係
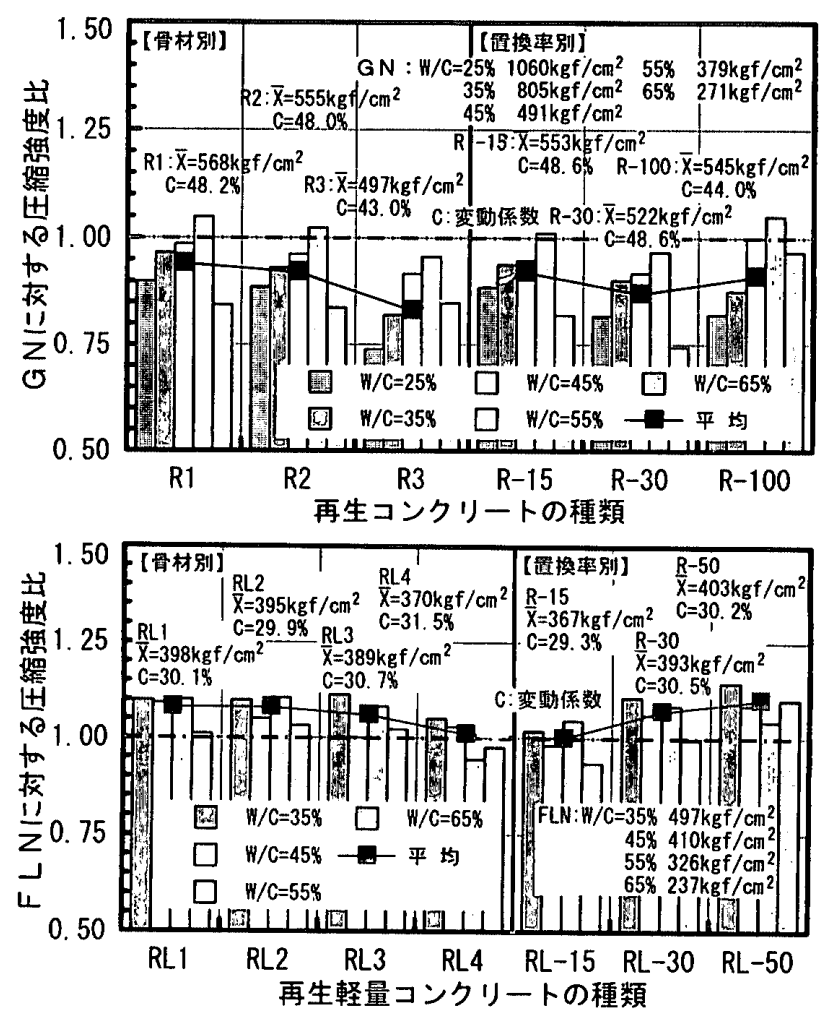

图-8 各種コンクリートの 4 週圧樎強度試験結果

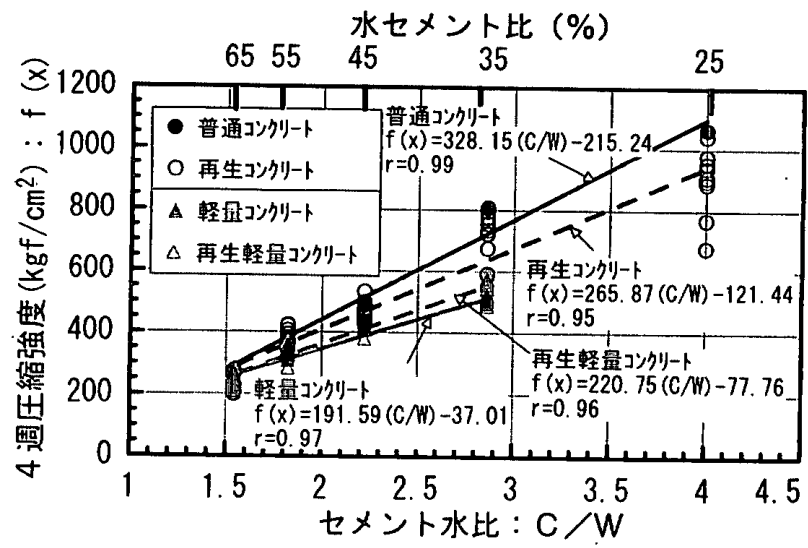

図－9 各種コンクリートの狄水比と 4 週王縮強度の関保 
図一 10 に、再生コンクリートおよび再生軽量コンク リートの 4 週王樎強度と 4 週引張および 4 週曲げ強度と の関係を示す。これによると、 4 週引張および 4 週曲げ 強度ともに 4 週王䄸強度と高い相関がみられた。また、 相対的には、再生コンクリートの 4 週曲げ強度が高強度 域で普通コンクリートに比へ若干低下したが、他は普通 コンクリートおよび軽量コンクリートとほぼ一致した。

\section{(4) 乾燥収箖}

図－11に各種コンクリートの乾燥収縮試験結果の一 例として、水セメント比 $55 \%$ の場合における測定結果 を示す。これによると、畭燥期間 26 週における乾燥収 縮率は、再生コンクリートでほぼ $7 \sim 9 \times 10^{-4}$, 再生軽 量コンクリートで $8 \sim 11 \times 10^{-4}$ であり、1975年版JASS 5 解説（ 2 節）に示された「常用」コンクリートの品質の 目標値「8 $8 \times 10^{-4}$ 以下」を越えるものが多かった。

また、全体的な㑯向として、原コンクリートの強度が 小さい程，また、置換率が大きくなるのに伴って乾燥収 縮率も大きくなる㑯向にあった。

乾燥期間 52 週までの実湘値をもとに回帚式により推 定した再生コンクリートおよび再生軽量コンクリートの

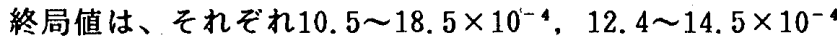
の範囲内となり、前者で普通コンクリートに比べて 1.1 〜 2 倍, 後者で軽量コンクリートに比べて1.1〜1.3 倍 程度大きな値となった。

なお、再生軽量コンクリートにおいては、細骨材・粗 骨材ともに $15 \%$ 置換したものと、粗骨材のみ $30 \%$ 置 換したものの終局収䈹値はほぼ同程度であった。

図ー 12 に、水セメント比および固換率の翼なるコン クリートの単位水量と 26 週乾嬠収樎率の関係を示す。

原コンクリートの強度が大きい再生骨材を用いた上で、 細・粗骨材の置換率を $30 \%$ 以下とし、さらに、単位水 量を $185 \mathrm{~kg} / \mathrm{m}^{3}$ 以下にすることにより、8 $8 \times 10^{-4}$ 以下 に適合する収縮率のコンクリートが得られるといえる。

\section{（5）中性化および塩分遮蔽性}

図一 13 に、水セメント比 $35 \% ， 55 \%$ 各種コン クリートの促進中性化および塩分浸透試験の結果を骨材 種類および置換率別にプールして平均した値で示す。

これによると、再生コンクリートおよび再生軽量コン クリートの中性化梁さは普通コンクリートおよび軽量コ ンクリートと同程度であった。

水セメント比が中牲化梁さに及ぼす影㸷については、 再生軽量コンクリートでより顕著であった。このように、 再生コンクリートおよび再生軽量コンクリートの中性化 深さが、普通および軽量コンクリートのそれと同程度で あった理由としては、単位セメント量が前者でやや多い ことによるものといえる。

一方、塩分浸透樑さについては、全体としては中性化 と同様な傾向がみられた。しかし、再生軽量コンクリー

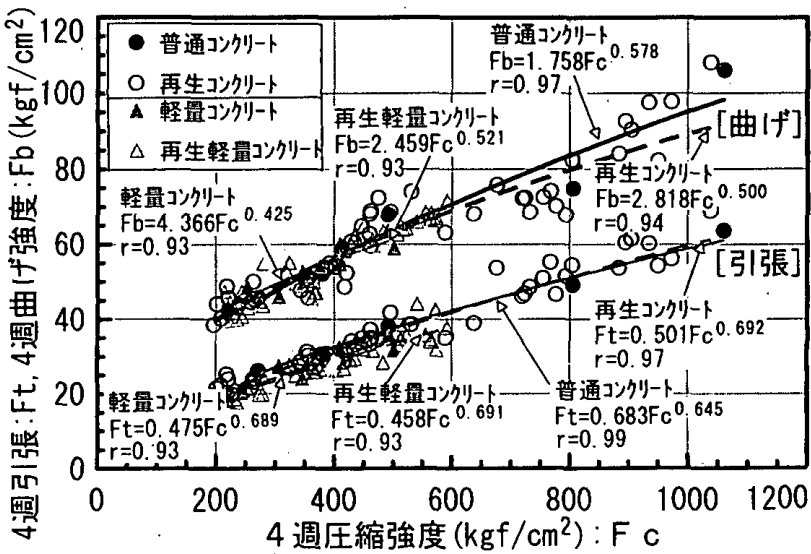

図一 10 各種コンクリートの 4 週圧縮強度と 4 週引張強度 および 4 週曲げ強度の関係

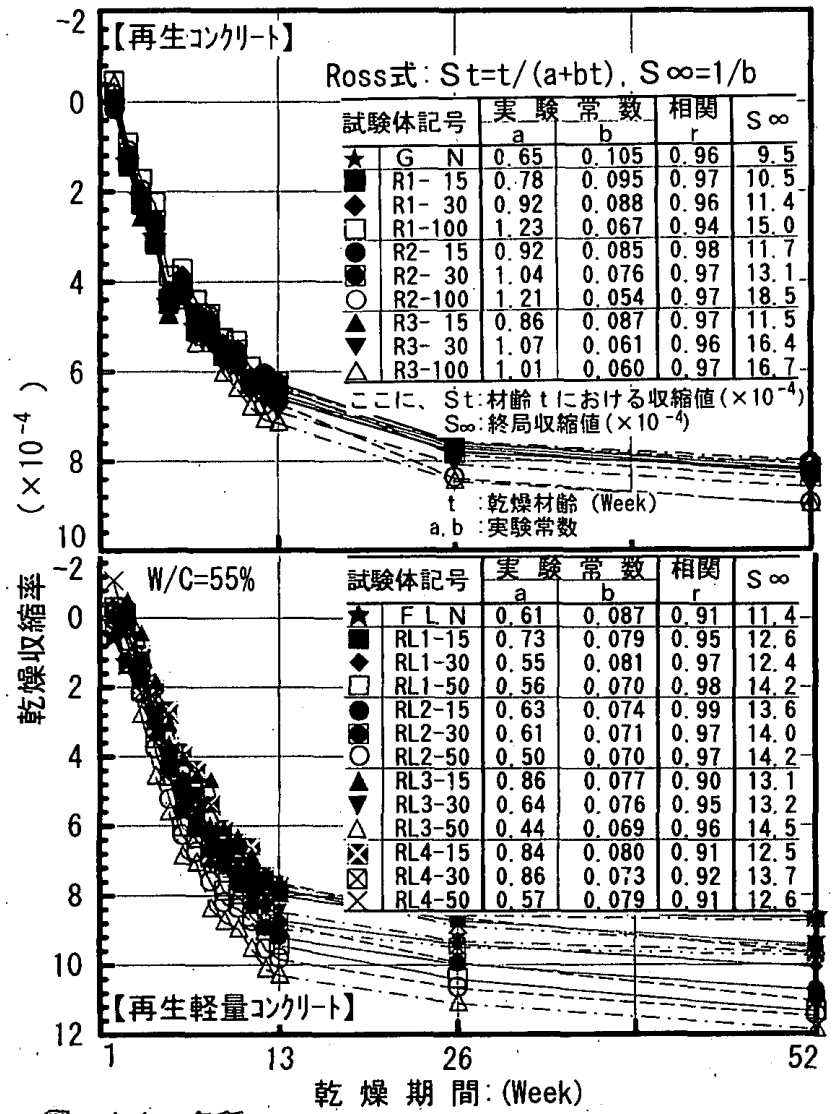

图-11 各種コンクリートの乾嬠収䈹試験結果の一例 （水セメント比 $55 \%$ )

トについては、水セメント此 $55 \%$ とした場合、再生コ ンクリートに比べて、全体的に大きな塩分浸透深さを示 すことから、コンクリートの調合に際して水セメント比 の設定には十分な配慮が必要である。

\section{（6）耐久性指数}

図－14に、水セメント比 $55 \%$ の各種コンクリート の耐久性指数の測定結果を示す。再生コンクリートの耐 久性指数は、300 サイクル時でいずれも $90 \%$ 以上の 值であり、普通コンクリートと同等であった。

これに対して再生軽量コンクリートでは 90 ～ 120 
サイクルで耐久性指数 $60 \%$ 以下となった。

また、軽量コンクリートに比へて、凍結瀜解に対する 抵抗性はやや少るといえる。

\section{5. 骨材物性とコンクリートの諸物性の関你}

4-2-2. で示したように、硬化した再生コンクリ ートおよび再生軽量コンクリートの品質は、使用する再 生骨材，再生軽量骨材のの物性のみでなく、置換率を含 んだ複数の因子の影幚を受けることが確認できた。

従って、再生コンクリートの品質を定量的に推湘する ためには、これらを包含した相対的な品質を評価軸とし て、それとの相関性で検討するのが適切な方法といえる。

そこで本項では、骨材の物性と置換率を因子として求 めた相対品質值を評価軸として、コンクリートの品質と の相関性について検討を行うこととした。

\section{5-1. 骨材の相対的な品質の求め方}

骨材の相対的な品質については、（1）式に示すように、 使用する骨材の物性値とその絶対容皘の皘の和を、使用 した全骨材の絶対容皘の和で除して求めている。（ただ し、骨材強度等、骨材の品質值が粗骨材のみの場合は(2) 式による。）。

なお、骨材強度については、 $3-3 （ 6 ）$ で述へたよ うに実皘率の影響が大きいことから、（3）式に示す方法 で求めた値を相対品質値とした。

$$
\begin{aligned}
& Q_{t}=\frac{[Q v G \times a+\theta r G \times b]+[Q v N \times c+\theta r N \times d]}{a+b+c+d} \\
& \mathbf{Q} \mathbf{t}=\frac{[Q v G \times a+\theta r G \times b]}{a+b}
\end{aligned}
$$

ここに、

Qt：再生（軽量）コックリートに用快骨材の相対品質値 $Q t^{\prime}$ : 実積率による補正品質値

QvG: 再生（整量）コンクリートに用い原粗骨材物性値 QvN: 再生（軽量）コンクリートに用いた原細骨材物性值 QrG: 再生 (軽量) コックリートに用屿再生(軽量)粗骨材物性值 QrN: 再生 (軽量) コックリートに用屿再生 (軽量) 細骨材物性值

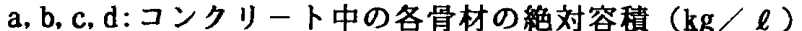
$\beta$ : 補正係数 $(\beta=\mathrm{K} /$ [各種骨材の実皘率] $)$

$\mathrm{K}$ : 実匼常数 $(60 \pm 5 \%)$

※実酫常数は、筆者らが行った実皘率に関する一連の実 験結果 ${ }^{15)}$ を統計处理して定めたもので、本検討では、 $60 \%$ を採用している。

\section{5-2 王樎搏度との関你}

4-2-2（2）で示したように、再生コンクリート および再生軽量コンクリートの 4 週死缩強度は、骨材の 種類および置換率の影隌が大きい。

図一 15 に、再生骨材の相対 $40 \mathrm{t}$ 破碎值と再生コン クリートの 4 週王縮強度の関係を示す。これによると、 $600 \mathrm{kgf} / \mathrm{cm}^{2}$ を越えるものにおいては、相対 $40 \mathrm{t}$ 破 砕値が大きくなるのに伴い 4 週圧䈹强度は小さくなる傾

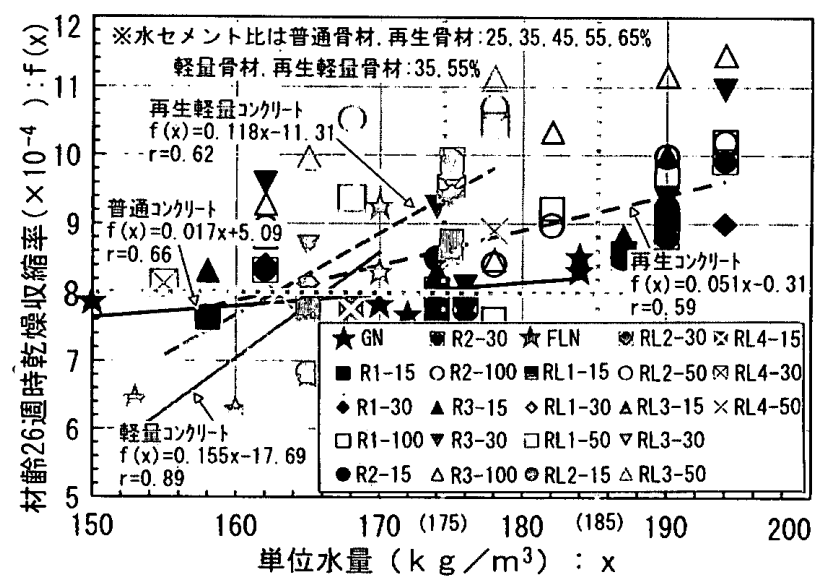

図-12 各種コンクリートの単位水量と乾嬠収䈹率の関係

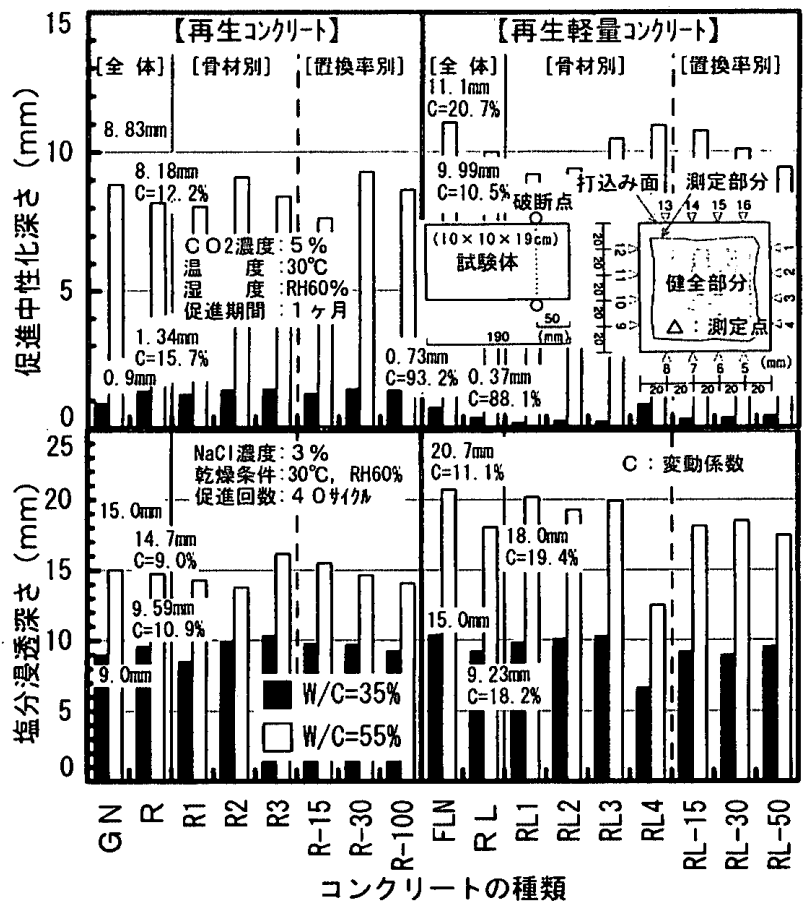

图ー13 各種コンクリートの促進中性化および塩分浸透 試験結果

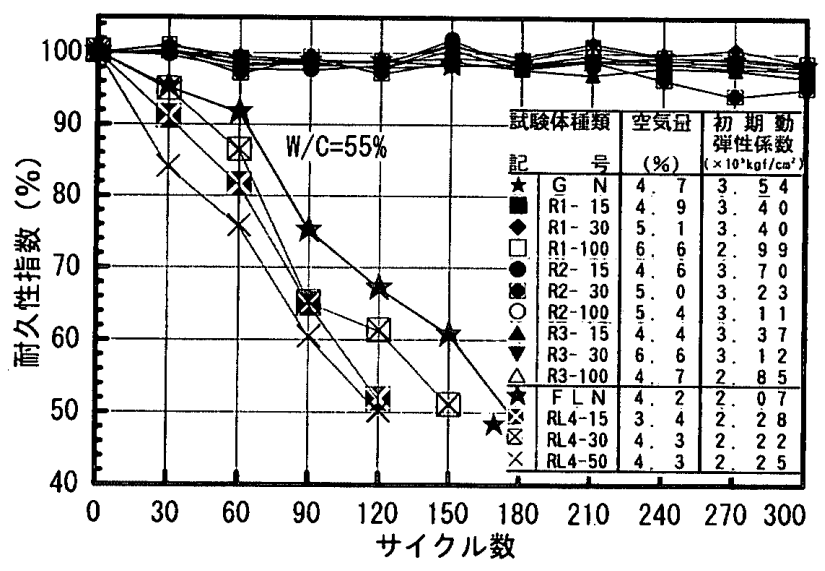

图－14 各種コンクリートの凍結融解試験結果の一例 （水セメント比 $55 \%$ ） 


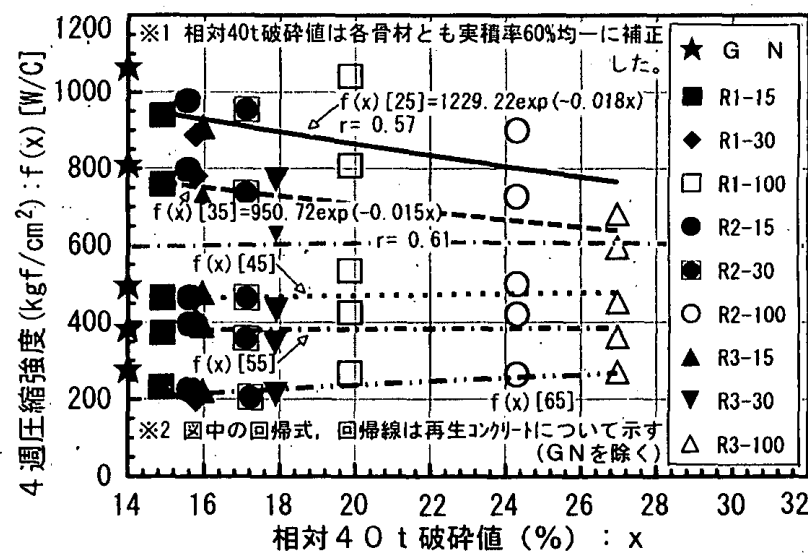

园-15 普通骨材, 再生骨材の相対 $40 \mathrm{t}$ 破砕值と コンクリートの 4 週压縮強度の関係

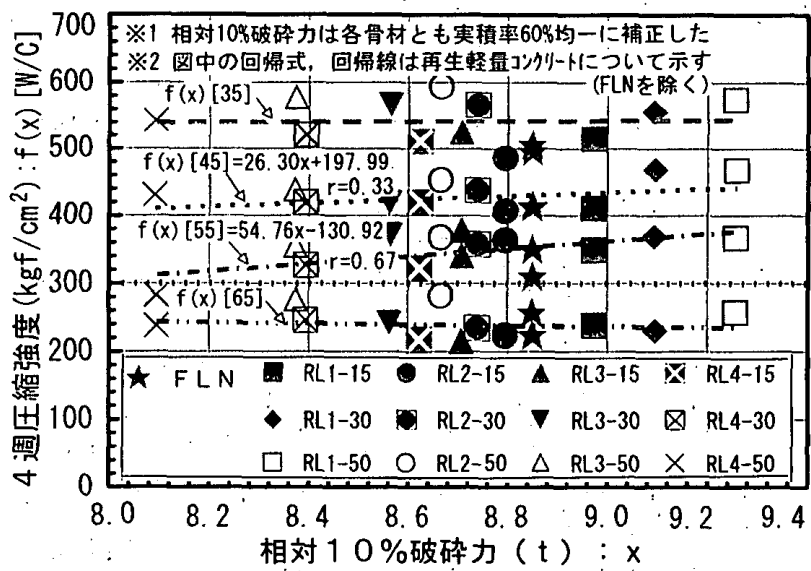

图-16 軽量骨材, 再生軽量骨材の相対 $10 \%$ 破硴力之 コンクリートの 4 週压䈹強度の関係

向を示し、相関係数も0.57〜0.61と比較的明確な相関性 がみられた。

また、図一-16 は、再生軽量骨材の相対 $10 \%$ 破砕力 と再生軽量コンクリートの 4 週王篗強度の関係を示した ものである。3 $00 \mathrm{kgf} / \mathrm{cm}^{2}$ を越えると相対 $10 \%$ 破砕 力が大きくなるのに伴い 4 週圧樎強度も大きくなる㑯向 を示し、一部には相関性の高いものもみられたが、強度 区分の影響は明確にはみられなかった。

図一１７に再生骨材および再生軽量骨材の相対吸水率 とそれら骨材を用いたコンクリートの 4 週圧縮強度の関 係を示す。これによると、再生コンクリ一トは、300 $\mathrm{kgf} / \mathrm{cm}^{2}$ を越えると相対吸水率が大きくなるのに伴い 4 週 王箱強度は小さくなる㑯向がみられ、さらに $600 \mathrm{0gf} /$ ccil゙を越えるものにおいてはその傾向が顕著になり、相関 係数も $0.59 \sim 0.63$ と比較的明確な相関性がみられた。

一方、再生軽量コンクリートは、各水準ともに相対吸水 率が大きくるのに伴い4週圧䈹強度は小さくなる㑯向 がみられ、一部には相関性の高いものもみられたが、強 度区分の影嘒は明確にはみられなかった。

以上のことから、再生コンクリートおよび再生軽量コ

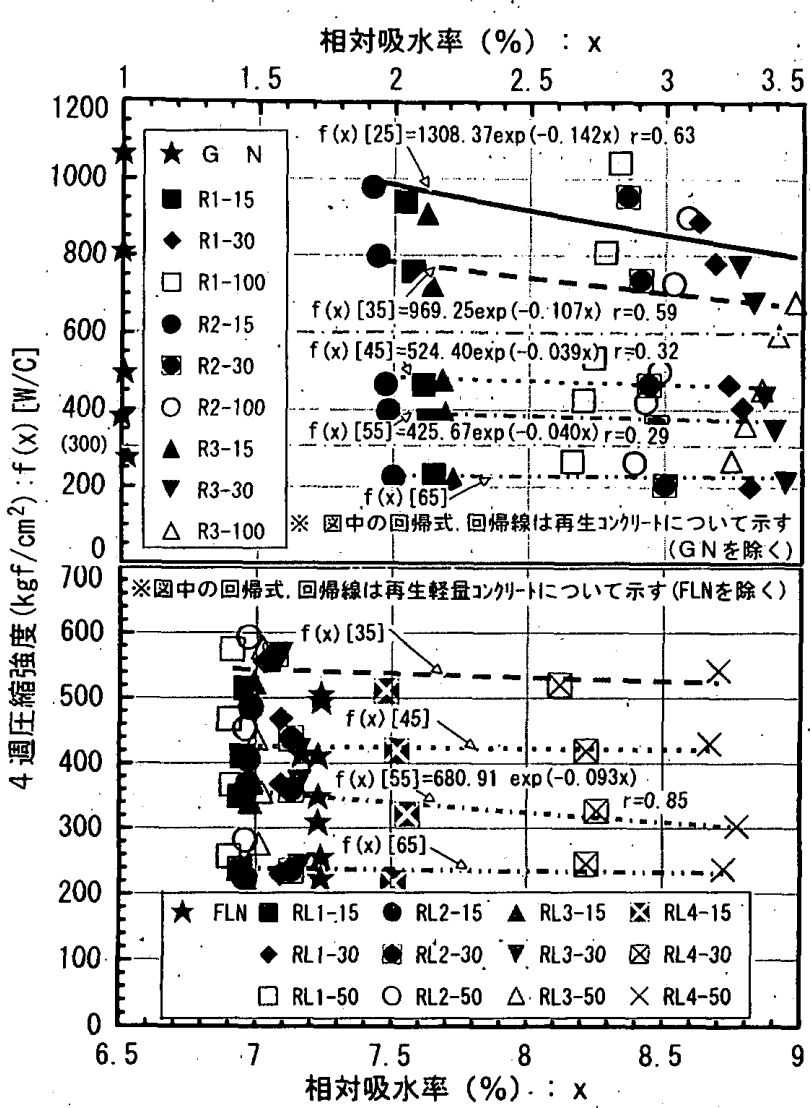

图一１7 各種骨材の相対吸水率とコンクリートの 4 週圧縮強度の関係

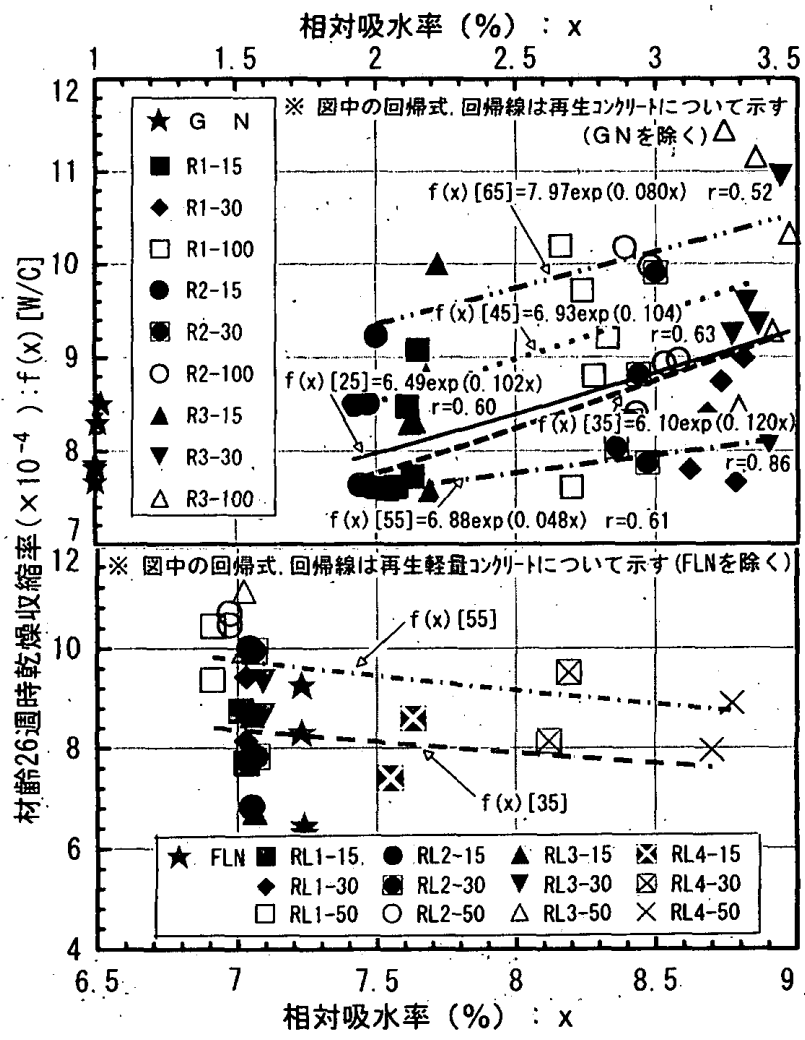

图一-18 各種骨材の相対吸水率とコンクリートの 乾燥収縮率の関係 
ンクリートの 4 週庄䈹強度は、本方法で定量的に推測す ることが可能であるといえる。

\section{$5-3$ 乾燥収蒋との関保}

4-2-2（4）で示したとおり、再生コンクリート およひ再生轻量コンクリートの乾燥収樎は、4 週圧樎強 度同様、骨材の種類およびその置换率の影㫪が大きい。

図－18 に、再生骨材および再生軽量骨材の相対吸水 率と、それら骨材を用いたコンクリートの 26 週乾燥叹 穛率の関係を示す。これによると、再生コンクリートで は、相対吸水率が大きくるのに伴い乾燥収樎率も大き くなる㑯向がみられ、相関係数も0.52〜0.86と比較的高 い。

また、相対吸水率 $1.8 \sim 3.5 \%$ 範囲では、相対吸水 率 $1 \%$ の増加に対して、2 6 週乾燥収樎率が $0.4 \sim 1.0$ $\times 10^{-4}$ 程度大きくなることが推測できる。このことから、 本方法により再生コンクリートの品質で実用上最大の問 題である乾燥収籍率についても定量的に推測できるとい える。

一方、再生軽量コンクリートでは、各水準ともに骨材 の影輻は明確にはみられなかった。

\section{5-4その他のコンクリート物性との関保}

上記以外の骨材の相対品質值とコンクリート品質の関 係については、本検討の笧囲で明確な相関はみられなか った。

\section{6.まとめ}

再生骨材および再生軽量骨材の品質が再生コンクリー トおよび再生軽量コンクリートの品質に及ぼす影㸷を解 明するため、各因子との相関性について検討を行った結 果、大要以下のような知見が得られた。

（1）骨材物生のうち、吸水率，実積率および骨材強度 は、再生コンクリートおよび再生軽量コンクリートの品 質に与える影響が大きく、骨材品質を評価する物性とし て重要である。また、これらの諸物性は原コンクリート の圧䈹強度の影響が大きい。

（2）全体的に再生コンクリートおよび再生軽量コンク リートの品質は、乾燥収縮を除き、ほぼ普通コンクリー トおよび軽量コンクリートの品質の範囲内にある。

従って、乾燥収樎低隇を考慮して、適切な骨材の品質 管理および調合設計を行うことにより、構造用コンクリ ートとしての適用が可能である。

(3) 相対 $40 \mathrm{t}$ 破碀值および相対吸水率と再生コンク リートの 4 週圧箖強度には相関性がみられ、その㑯向は 高強度のコンクリートほど明確である。

（4）相対吸水率と再生コンクリートの乾嬠収樎率は比
較的明確な相関関係がみられた。従って、使用する骨材 全体の物生を相対的に評価することにより、乾燥収樎率 を定量的に推湘することが可能である。

（5）再生軽量コンクリートについては、相対 $10 \%$ 破 确力および相対吸水率と 4 週圧樎強度の間で、やや相関 がみられたが、他の相対品質値とコンクリートの品質の 間には、明確な相関はみられない。

（6）以上のことから、再生コンクリートの品質につい ては、本検討で提案した相対品質値を用いることにより、 コンクリートに要求される重要な品質について定量的に 推測することが可能である。

\section{謝 辞}

本研究の実施にあたりまして、（財）建材武験センタ 一楖 啓氏，日本メサライト工業林）山下時夫氏およ び明治大学卒諭生 須川英樹氏(1991 年度), 松田和昭氏 (1992 年度), 小椋貴光氏(1993 年度), 小林祐介氏(1994 年度）に多大の御協力を睗りました。ここにそのことを 記し、厚く謝意を表します。

\section{考文献}

1）菊池雅史，道正泰弘 安永 亮 増田 彰：「俥量コンクリート 1 種を破碎して得られた骨材を用いたコンクリートの基礎的性状に 関する研究（その1〜2）」日本建築学会大会学術講演梗概集（東 海) pp369-372 1994.9

2）菊池雅史，道正泰弘 安永 亮他：「再生軽量骨材を用いたコン クリートの基礎的性状に関する研究（その $1 \sim 2)$ 」 日本建筑学会 大会学術講演梗概集 (関東) pp409 412 1993.9

3）菊池雅史，安永 亮他：「再生骨材およびそれを用いたコンクリ 一トの総合評価に関する研究（その1〜2）」日本建築学会大会学 術講演梗概集（北陸）pp557 〜560 1992.8

4) Masafumi KIKUCHI, Akira YASUNAGA, Kyouji EHARA;The Tota1 evaluation of Recycled Aggregate and Recycled Concrete, RILEI, Yo1 33, pp. 367-377, 1994

5）（盰）建策業協会 建設廃棄物処理再利用委員会（委員長 笠井 芳夫）「再生骨材コンクリートに関する研究」コンクリート工学 Vo1 16 pp18 31 1978. 7

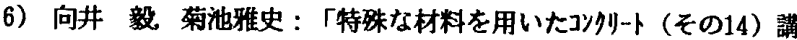
座 再生骨材」コンクリート工学 Vo1. 25 No. 1 pp103-108 1987.1 7）（財）建築業協会 建設廃裹物処理・再利用委員会：「コンクリ 一下解体物の再利用に関する研究報告書」昭和 51 年 3 月

8）（盯）国土開発技術研究センター「建設事業への廃棄物利用技術 の開発に関する調查報告書」昭和 61 年 3 月

9）(时）国土開発技術研究センタ一「再生コンクリート利用技術の 開発 平成 5 年度報告書」平成 6 年 3 月

10）龙沢史紀他：「完全リサイクルコンクリート(Iココンクリート)の研究」

日本建栄学会大会学術諈演梗概集 (東海) pp341-342 1994.9

11）平賀謙一 箦沢和久「㪕量コンクリートの施工」丸善 昭和 35 年

12）霝見軍治 鴄谷宏文：「コンクリート用骨材の破砕値とコンクリ 一トの強度」セメント技術年報 Vol. 19 pp292-297 昭和 41 年

13）西林新葴他：「再生コンクリートに関する基礎的研究」セメント 技術年報 Vol. 36 pp147-150 1982

14）鳥居和之他：「再生骨材の埔装コンクリート用骨材としての嗃用 性」コンクリート工学年次陆演論文集 pp85-88 1984

15）例えば、向井 媇，菊池雅史，市川信雄：「コンクリート破碎物 およびそれを用いたコンクリートの性質に関する研究」セメント 技 術年報 Vol. 35 pp150-153 1981

(1995年 3 月 10 日原稿受理， 1995年 5 月 9 日採用決定) 